FACTA UNIVERSITATIS

Series: Physical Education and Sport, Vol. 18, No 2, 2020, pp. 447 - 456

https://doi.org/10.22190/FUPES200222042K

Research article

\title{
SOCIODEMOGRAPHIC FACTORS AND LOW BACK PAIN IN MUNICIPALITY PHYSICAL ACTIVITY PROGRAMS FOR FEMALE PARTICIPANTS
}

\author{
UDC 796:63
}

796.01

\author{
Ioannis Kosmas', Yannis Georgiou ${ }^{2}$, \\ Eleni Marmara ${ }^{3}$, Aggeliki Fotiou ${ }^{4}$ \\ ${ }^{1}$ Department of Informatics and Telematics, Harokopio University of Athens, Athens, Greece \\ ${ }^{2}$ School of Physical Education and Sport Science, National and Kapodistrian University of \\ Athens, Athens, Greece \\ ${ }^{3}$ Health Center of Aigaleo, Athens, Greece \\ ${ }^{4}$ Department of Sports Organization and Management, University of Peloponnese, Sparta, Greece
}

\begin{abstract}
The purpose of this study was to investigate the relationship between low back pain $(L B P)$ and factors such as education level and years of work in 131 women aged $42 \pm 1.10$ years, participating in the "Sports for All" municipal physical activity (PA) programs in Greece. To evaluate how PA affects the intensity of pain, the questionnaires "Grading the Severity of Chronic Pain-GSCP" and the "A Fear-Avoidance Beliefs Questionnaire-FABQ" were used. Analysis of Variation and the Tuckey post hoc tests calculated the difference among the questions of each of the questionnaires. Statistically significant differences were determined for three questions. Female participants with a medium or low level of education show less or no improvement in LBP. Concerning years of work, participants with fewer years of work suffer from higher LBP levels than the ones already working for longer time. Future studies of the relationship between specific PA programs, the content and nature of one's job and the appearance of LBP are needed.
\end{abstract}

Key words: Low Back Pain, Intensity, Working Experience, Education Level

Received February 22, 2020 / Accepted August 13, 2020

Corresponding author: Yannis Georgiou

School of Physical Education and Sport Science, National and Kapodistrian University of Athens, Athens, Greece Phone: + 30 (694) 4838939•E-mail: georgiougiannis72@gmail.com 


\section{INTRODUCTION}

Low back pain (LBP) constitutes a common daily problem for the general population and is recognized by the medical community as a very important public health problem with particular economic and social implications. LBP results in reduced productivity due to reduced working time, increased absenteeism, and early retirement due to disability, while also contributing to poor quality of life as it negatively affects both physical as well as one's mental, emotional and social well-being (Shahzad, 2017).

Leclerc et al. (2009) reported that the two dominant categories of LBP relate to either factors of the work environment (movement mode, content, and type of work, loads, years of work, etc.), or demographics and the sociological characteristics that shape employees' lifestyles (gender, age, education level, tobacco and alcohol consumption, etc.). The socioeconomic status of individuals, as a multifactorial approach to the phenomenon, is a factor that significantly influences the occurrence of LBP (Ikeda et al., 2019). Other variables that affect LBP concern the socio-economic level of the participants, in particular level of education and years of work.

Research results have shown that low education levels correlate with various diseases and pathological conditions, including musculoskeletal diseases and more particularly LBP (Dionne et al., 2001; Hagen, Zwart, Svebak, Bovim, \& Stovner, 2005; Aittomäki, Lahelma, Rahkonen, Leino-Arjas, \& Martikainen, 2007; Schmidt et al., 2007). In particular, a negative correlation between education level and LBP has been reported in research, with participants with low or intermediate levels of education suffering more from LBP, and an even stronger correlation with participants reporting lower levels of education; on the other hand, for participants with higher education levels the only correlation found was when they were in a driving position for more than four hours (Shiri et al., 2019). The relative risk of suffering from LBP appears to be higher for those with low education levels compared with those with higher levels of education (Ikeda et al., 2019).

Several researchers' findings that studied the relationship between years of work and LBP appear to be inconsistent, but rather divergent. More specifically, the results of studying the relationship between LBP and with limited activity show a positive association of the intensity of LBP and age, and years of work (Loy, Warner-Czyz, Tong, Tobey, \& Roland, 2010). On the contrary, a different survey (Wami, Abere, Dessie, \& Getachew, 2019) regarding LBP among hotel employees showed that these employees with fewer working years had higher rates of LBP compared to those who had many years of work. In 2018 Lallukka and associates, after 28 years of research in the field, concluded that employees with few years of work presented statistically significantly higher levels of LBP compared to those who already worked for more years. In addition, in the same study, women were more likely than men to report having LBP, with those with a low level of education reporting having LBP more often.

Many studies have focused on physical activity (PA) and exercise as a means of reducing $\mathrm{LBP}$, reducing movement restrictions due to pain, and reducing the fearavoidance feeling concerning movement due to pain, while also improving the patients' overall quality of life (Kosmas, Georgiou, Marmara, \& Fotiou, 2019; Salas et al., 2019; Vanti et al., 2019; Đurđević, Mazić, Janković, \& Isaković (2019). In Greece, popular PA programs named "Sports for All", aimed at mass citizen participation in PA and exercise activities, are primarily focused on improving the health of the participants in total, contributing significantly to the improvement of public health. These programs are implemented by Municipal Sports Organizations on municipal premises and refer to female 
trainees (Alexandris, Papadopoulos, Palialia, \& Vasiliadis, 1999; Afthinos, Theodorakis, \& Nassis, 2005). However, these programs follow specific standards in their content that refer to the general population and not to participants with specific characteristics such as those suffering from LBP.

The literature review does not show any research attempt involving a group of women participating in municipal PA programs who suffer from LBP. More specifically, there no research has been implemented to investigate the relationship between LBP and labor and social-demographic variables, such as education level and years of work. The purpose of this study is to investigate the relationship between LBP and the factors of education level and years of work among women participating in the "Sports for All" municipal PA programs in Greece.

\section{METHODS}

This survey was conducted from January 2017 to June 2017. From a population of approximately $n=1500$ women who participated in the "Sports for All" programs, those who reported suffering from LBP were $n=131$. The mean age of the women reporting LBP was $M=42 \pm 1.10$ while the two extremes were identical to the values of those of the total sample ( $\min =18$ and $\max =66$ years).

To evaluate LBP intensity, the questionnaire "Grading the Severity of Chronic Pain" by Von Korff, Ormel, Keefe, and Dworkin (1992) was used. At the same time the Waddell, Newton, Henderson, Somerville, and Main (1993) "A Fear-Avoidance Beliefs Questionnaire (FABQ)" questionnaire was also used to measure whether and how PA affects the intensity of pain from the intra-articular corticosteroids.

The FABQ questionnaire consists of 8 questions on a five (5) point Likert scale rated from totally disagree (1) to totally agree (5). Concerning the GSCP, there are 8 questions on a ten (10) point Likert scale, from $0=$ no pain to $10=$ the worst possible pain (questions 1-4). The fifth question "For how many days, during the last six months, have you been absent from your usual activities (work, school, home, sports) due to back pain? (Number) days of abstinence". The sixth question, about the effect of pain on any activity, is rated from $0=$ no effect up to $10=$ impossible to exercise. The seventh question about changes in the ability to participate in creative/social/family activities due to pain is rated from $0=$ no change up to $10=$ huge change. The eighth question about the ability to participate in creative/social/family activities due to pain is rated from 0 up to 10 where $0=$ no change and 10=huge change. For the GSCP questionnaire the Cronbach $a$ coefficient ranged between 0.811-0.976, while for the FABQ questionnaire the Cronbach $a$ coefficient ranged between $0.877-0.984$.

The correlation in the test-retest control (questionnaire reliability) was within the accepted values. The reliability of an instrument is defined as its relation to the consistency or repeatability of the measurement (Thomas, Nelson, \& Silverman, 2015). In the present survey, the questionnaire was translated into the Greek language, completed by 55 persons. Furthermore, the questionnaire was redistributed to the same persons after 48 hours without them being informed beforehand that a test-retest control will take place to test the reliability (Chaory et al., 2004). The results of each question were separately and overall compared to those provided in the new questionnaire. 
Table 1 Test-retest control correlation

\begin{tabular}{|c|c|c|c|c|}
\hline & \multicolumn{2}{|c|}{ GSCP } & \multicolumn{2}{|c|}{ FABQ } \\
\hline Q1 & $p<0.01$ & 0.811 & $p<0.01$ & 0.977 \\
\hline Q2 & $\mathrm{p}<0.01$ & 0.976 & $p<0.01$ & 0.956 \\
\hline Q3 & $\mathrm{p}<0.01$ & 0.937 & $p<0.01$ & 0.853 \\
\hline Q4 & $p<0.01$ & 0.970 & $p<0.01$ & 0.951 \\
\hline Q5 & $p<0.01$ & 0.976 & $p<0.01$ & 0.984 \\
\hline Q6 & $p<0.01$ & 0.960 & $p<0.01$ & 0.877 \\
\hline Q7 & $p<0.01$ & 0.884 & & \\
\hline Q8 & $p<0.01$ & 0.925 & & \\
\hline $\mathrm{M}$ & & 0.929875 & & 0.933 \\
\hline
\end{tabular}

\section{RESULTS}

\section{Years of work}

The years of work reported by participants ranged from $\min =1$ to $\max =36$ and the mean was $M=14.25 \pm 0.795$ (Table 2). This shows us a level of variance concerning the participation's mass character of the PA programs, the different ages and the different work years of the participants.

Table 2 The average value and standard deviation for years of occupation

\begin{tabular}{lcc}
\hline \multirow{2}{*}{ Years of work } & Mean & Standard Deviation \\
\cline { 2 - 3 } & 14.25 & 0.795 \\
\hline
\end{tabular}

The descriptive statistics and the analysis of variance show that in three questions (Question 12b Question Q4, Question Q5) there are statistically significant differences $F$ $(5,125)=4.07, p=0.002, F(5,125)=3.49, p=0.05, F(5,125)=5.09, p=0.000$, respectively. No statistically significant differences were observed for the remaining questions $(p<0.05)$.

The Tukey post hoc analysis of statistically significant differences between different groups of working years indirectly showed for Question $12 \mathrm{~b}$ "How will you rate at present the pain you feel?" there was a statistically significant difference between women who had 1 to 6 years of experience at work $(M=4.44 \pm 1.48)$ and women with working experience of 13-18 years $(M=3.34 \pm 0.70)$. In other words, participants with most years of work experienced less LBP at present, while those with fewer years of work declared significantly higher levels of pain. For Question Q4 "I should not do activities that could aggravate my pain", there was a statistically significant difference between participants with 1-6 years of work experience $(M=5.69 \pm 1.63)$ and participants with 13-18 years of work experience $(M=4.21 \pm 1.33)$. Participants with fewer years of work were more determined to participate in activities that would make their LBP worse than the participants who had more years of work. Similarly, for Question Q5 "I cannot do activities that would exacerbate my pain" there was a statistically significant difference between participants who had 1-6 years of work experience $(M=5.08 \pm 1.77)$ and participants whose work experience was $13-18$ years $(M=3.18 \pm 1.61)$. This shows that women in training programs with fewer years of work experience are not willing to do activities that would exacerbate their pain, while participants who worked more years (13-18) were not sure if their LBP would be worsened or not. 
Table 3 Descriptive statistics and ANOVA of years of work

\begin{tabular}{|c|c|c|c|c|c|c|}
\hline Question & $\begin{array}{l}\text { Source of } \\
\text { Variance }\end{array}$ & $\begin{array}{l}\text { Sum of } \\
\text { squares }\end{array}$ & df & $\begin{array}{c}\text { Mean } \\
\text { Squares }\end{array}$ & $\mathrm{F}$ & $\mathrm{p}$ \\
\hline \multirow[t]{3}{*}{ que12a } & Groups & 12.188 & 5 & 2.438 & 1.766 & .125 \\
\hline & Error & 172.545 & 125 & 1.380 & & \\
\hline & Total & 184.733 & 130 & & & \\
\hline \multirow[t]{3}{*}{ que12b } & Groups & 30.325 & 5 & 6.065 & 4.078 & $.002^{*}$ \\
\hline & Error & 185.904 & 125 & 1.487 & & \\
\hline & Total & 216.229 & 130 & & & \\
\hline \multirow[t]{3}{*}{ que12c } & Groups & 3.512 & 5 & .702 & .631 & .677 \\
\hline & Error & 139.190 & 125 & 1.114 & & \\
\hline & Total & 142.702 & 130 & & & \\
\hline \multirow[t]{3}{*}{ que12d } & Groups & 2.638 & 5 & .528 & .470 & .798 \\
\hline & Error & 140.278 & 125 & 1.122 & & \\
\hline & Total & 142.916 & 130 & & & \\
\hline \multirow[t]{3}{*}{ que12e } & Groups & 22.787 & 5 & 4.557 & 1.260 & .285 \\
\hline & Error & 452.130 & 125 & 3.617 & & \\
\hline & Total & 474.916 & 130 & & & \\
\hline \multirow[t]{3}{*}{ que12f } & Groups & 13.961 & 5 & 2.792 & 1.195 & .315 \\
\hline & Error & 291.948 & 125 & 2.336 & & \\
\hline & Total & 305.908 & 130 & & & \\
\hline \multirow[t]{3}{*}{ que12g } & Groups & 15.040 & 5 & 3.008 & 2.223 & .056 \\
\hline & Error & 169.128 & 125 & 1.353 & & \\
\hline & Total & 184.168 & 130 & & & \\
\hline \multirow[t]{3}{*}{ que12h } & Groups & 3.297 & 5 & .659 & .405 & .845 \\
\hline & Error & 203.603 & 125 & 1.629 & & \\
\hline & Total & 206.901 & 130 & & & \\
\hline \multirow[t]{3}{*}{ Q1 } & Groups & 10054 & 5 & 2.011 & .719 & .610 \\
\hline & Error & 349.488 & 125 & 2.796 & & \\
\hline & Total & 359.542 & 130 & & & \\
\hline \multirow[t]{3}{*}{$\mathrm{Q} 2$} & Groups & 11.781 & 5 & 2.356 & 1.265 & .283 \\
\hline & Error & 232.769 & 125 & 1.862 & & \\
\hline & Total & 244.550 & 130 & & & \\
\hline \multirow[t]{3}{*}{ Q3 } & Groups & 2.320 & 5 & .464 & .194 & .964 \\
\hline & Error & 298.474 & 125 & 2.388 & & \\
\hline & Total & 300.794 & 130 & & & \\
\hline \multirow[t]{3}{*}{ Q4 } & Groups & 40.228 & 5 & 8.046 & 3.498 & $.005^{*}$ \\
\hline & Error & 287.497 & 125 & 2.300 & & \\
\hline & Total & 327.725 & 130 & & & \\
\hline \multirow[t]{3}{*}{ Q5 } & Groups & 71.443 & 5 & 14.289 & 5.091 & $.000^{*}$ \\
\hline & Error & 350.802 & 125 & 2.806 & & \\
\hline & Total & 422.244 & 130 & & & \\
\hline \multirow[t]{3}{*}{ Q6 } & Groups & 18.245 & 5 & 3.649 & 1.728 & .133 \\
\hline & Error & 263.999 & 125 & 2.112 & & \\
\hline & Total & 282.244 & 130 & & & \\
\hline
\end{tabular}




\section{Level of education}

The level of education of the participants in PA programs is shown in Table 4. There are two prevailing levels of education. One is primary school graduates $(34.3 \%)$ and the other is junior high and high school graduates (48.9\%). Women who hold a university, postgraduate or doctoral degree are the least present (16.8\%).

Table 4 Level of training of participants in PA programs $(\mathrm{N}=131)$

\begin{tabular}{lrr}
\hline & $\mathrm{N}$ & $\mathrm{f}(\%)$ \\
\hline Primary School & 45 & 34.3 \\
Junior High School-High School & 64 & 48.9 \\
University & 22 & 16.8 \\
\hline Total & 131 & 100.0 \\
\hline
\end{tabular}

Table 5 shows statistically significant differences for three questions (Question 12c Question 12d, Question 12f, respectively), $[F(2.128)=5.93, p=0.003, F(2,128)=4.02$, $p=0.020, F(2,128)=6.65, p=0.002]$. No statistically significant differences were observed for the remaining questions $(p<0.05)$.

The Tukey post hoc analysis of statistically significant differences showed that for Question 12c "During the last six months how intense was the worst LBP you felt" there was a statistically significant difference between participants who were primary school graduates $(M=3.93 \pm 1.07)$ and participants who were junior high school and high school graduates $(M=3.26 \pm 0.97)$. Interpreting this means that the primary school graduate participants felt more intense pain than the junior high or high school graduate participants.

For Question 12d "During the last semester and on average, how severe was the LBP you felt?" a statistically significant difference was noted between primary school graduate participants $(M=3.84 \pm 0.97)$ and junior high school and high school graduate participants $(M=3.36 \pm 1.09)$. The usual pain that the primary school graduate participants felt was on average more pronounced than that of the junior high school-high school participants during the last semester.

For Question 12e "How many days in the last semester did you abstain from your usual activities (work, school, home, sports) due to LBP (days off)" a statistically significant difference was noted between primary education graduate participants $(M=5.2 \pm 1.53)$ and junior high school- high school group of participants $(M=4.15 \pm 1.55)$. The number of days of absence from various activities of the first group of graduates was higher than that of the second group, respectively.

For Question $12 \mathrm{f}$ "During the last semester, how much did the LBP affect you in your daily activities in your daily activities?" no statistically significant differences were found between participants with different levels of education. 
Table 5 Descriptive statistics and ANOVA of the level of education

\begin{tabular}{|c|c|c|c|c|c|c|}
\hline Question & $\begin{array}{l}\text { Source of } \\
\text { Variance }\end{array}$ & $\begin{array}{l}\text { Sum of } \\
\text { squares }\end{array}$ & df & Mean squares & $\mathrm{F}$ & $\mathrm{p}$ \\
\hline \multirow[t]{3}{*}{ que $12 \mathrm{a}$} & Groups & 2.569 & 2 & 1.285 & .903 & .408 \\
\hline & Error & 182.164 & 128 & 1.423 & & \\
\hline & Total & 184.733 & 130 & & & \\
\hline \multirow[t]{3}{*}{ que $12 b$} & Groups & 3.474 & 2 & 1.737 & 1.050 & .355 \\
\hline & Error & 212.755 & 128 & 1.662 & & \\
\hline & Total & 216.229 & 130 & & & \\
\hline \multirow[t]{3}{*}{ que12c } & Groups & 12.100 & 2 & 6.050 & 5.930 & $.003^{*}$ \\
\hline & Error & 130.603 & 128 & 1.020 & & \\
\hline & Total & 142.702 & 130 & & & \\
\hline \multirow[t]{3}{*}{ que $12 \mathrm{~d}$} & Groups & 8.452 & 2 & 4.226 & 4.023 & $.020^{*}$ \\
\hline & Error & 134.464 & 128 & 1.050 & & \\
\hline & Total & 142.916 & 130 & & & \\
\hline \multirow[t]{3}{*}{ que $12 \mathrm{e}$} & Groups & 18.209 & 2 & 9.104 & 2.552 & .082 \\
\hline & Error & 456.707 & 128 & 3.568 & & \\
\hline & Total & 474.916 & 130 & & & \\
\hline \multirow[t]{3}{*}{ que12f } & Groups & 28.816 & 2 & 14.408 & 6.656 & $.002^{*}$ \\
\hline & Error & 277.092 & 128 & 2.165 & & \\
\hline & Total & 305.908 & 130 & & & \\
\hline \multirow[t]{3}{*}{ que $12 \mathrm{~g}$} & Groups & 3.422 & 2 & 1.711 & 1.212 & .301 \\
\hline & Error & 180.746 & 128 & 1.412 & & \\
\hline & Total & 184.168 & 130 & & & \\
\hline \multirow[t]{3}{*}{ que12h } & Groups & 15.255 & 2 & 7.627 & 5.094 & $.007^{*}$ \\
\hline & Error & 191.646 & 128 & 1.497 & & \\
\hline & Total & 206.901 & 130 & & & \\
\hline \multirow[t]{3}{*}{ Q1 } & Groups & 11.966 & 2 & 5.983 & 2.203 & .115 \\
\hline & Error & 347.576 & 128 & 2.715 & & \\
\hline & Total & 359.542 & 130 & & & \\
\hline \multirow[t]{3}{*}{$\mathrm{Q} 2$} & Groups & 2.801 & 2 & 1.401 & .742 & .478 \\
\hline & Error & 241.749 & 128 & 1.889 & & \\
\hline & Total & 244.550 & 130 & & & \\
\hline \multirow[t]{3}{*}{ Q3 } & Groups & 8.176 & 2 & 4.088 & 1.788 & .171 \\
\hline & Error & 292.618 & 128 & 2.286 & & \\
\hline & Total & 300.794 & 130 & & & \\
\hline \multirow[t]{3}{*}{ Q4 } & Groups & 2.017 & 2 & 1.008 & .396 & .674 \\
\hline & Error & 325.708 & 128 & 2.545 & & \\
\hline & Total & 327.725 & 130 & & & \\
\hline \multirow[t]{3}{*}{ Q5 } & Groups & 4.835 & 2 & 2.417 & .741 & .479 \\
\hline & Error & 417.409 & 128 & 3.261 & & \\
\hline & Total & 422.244 & 130 & & & \\
\hline \multirow[t]{3}{*}{ Q6 } & Groups & .937 & 2 & .469 & .213 & .808 \\
\hline & Error & 281.307 & 128 & 2.198 & & \\
\hline & Total & 282.244 & 130 & & & \\
\hline
\end{tabular}

Legend: Significance set at level $* \mathrm{p}<0.05$ 


\section{DISCUSSION}

The purpose of this study was to investigate the relationship between education level, years of work and LBP among female participants of municipal mass sports programs "Sport for All". The determination of the relationship between socio-demographic factors and LBP, in participants in mass participation PA programs is an open field with a high research interest. In the research community there are insufficient research results regarding LBP issues related to proportionate factors, except very few studies that contribute significantly to their useful conclusions (Kosmas, Marmara, \& Stergioulas, 2008).

The results of this study concluded that female participants in the "Sport for All" PA program with a medium or low level of education show less or no improvement in LBP. These results are in line with resent results of the investigated area where the education level acts as a predictor of LBP (Alonso-García \& Sarría-Santamera, 2020). Probably the nature of the participants' work, due to their relatively low education level associated with elevated levels of physical job requirements and the specificity of the movements that the specific job requires, do not contribute to the reduction or the elimination of the symptom of LBP. The usual pain reported by participants with lower education levels participants was, on average, more intense than that of participants with higher education levels. The possible misunderstanding of the instructions given by the physical education (PE) teachers with the participants' level of education might be a factor which plays a key role in the final result of the intensity of LBP, such as misunderstanding the instructions by using obscene terms on behalf of the PE experts can lead to wrong execution on the part of the participants, which results in no improvement at all and can even be harmful. Besides, the number of days of absence from various activities (including work) of primary school graduates was more than those who had completed a junior high school-high school education, a finding which agrees with previous results (Dionne et al., 2001; Hagen et al., 2005; Schmidt et al., 2007; Aittomäki et al., 2007).

Concerning years of work, the results of the present study show that participants with fewer years of work declare that they suffer higher LBP levels than the ones already working for a longer time. Though the participants with fewer years of work seem to be more determined to follow PA programs that might make their LBP worse than participants with more years of work, they are less willing to do other kinds of activities that might exacerbate their LBP than those with more years of work. This specific ambiguity of the results of the present study can be reflected in the results of previous research. Some of them show that the severity and the levels of LBP where higher in the groups of participants with fewer years of work (Lallukka et al., 2018; Wami et al., 2019), while others surveys present their results that more years of work contribute to higher levels and more severe incidents of LBP (Loy et al., 2010). The conclusion that follows from the above is that the results of the present research are ambiguous, just like the results of previous research and no clear picture can be deduced. However, participants with more years of work felt less LBP, while those with fewer years of work had significantly higher LBP levels. This may indicate that the multitude of years of work creates a culture of prior knowledge which leads to experience and then acts as a deterrent to such phenomena.

The designers of such programs should also introduce specialized programs targeting a special population with special needs, among them individuals who suffer from LBP. Programs should be adapted to socio-demographic factors such as years of work and the education level of the participants. PE teachers should, on the one hand, formulate and 
adapt the content of the programs according to the physical condition of the participants, while on the other hand, they should use simple words without possible obscure scientific expressions, to make their instructions more comprehensible and thereby avoid any possible misunderstanding on the part of the participants that may lead to incorrect performance of some exercise, thus either creating or exacerbating an existing LBP problem.

This kind of segmentation should meet the challenges of our time, as we live in a very dynamic era where adaptation and flexibility are a must to any form of change. At the same time this gives an advantage to any sports organization if flexible and perhaps personalized programs are presented, with some of them based on the relationship between socioeconomic factors and the LBP. This would be a step in the right direction since it would not serve the impersonal implementation of programs, but the deeper purpose of mass sports programs which are ultimately to improve the physical, mental and social wellbeing of citizens, with direct and indirect beneficial effects.

\section{CONCLUSIONS}

It is likely that less educated women and people in general are engaged in manual or even heavy tasks that over the years lead to the emergence of LBP, while those with a higher level of education are occupied as specialized staff and in administrative positions. Future investigations of the relationship between specific PA programs and the content and nature of the job and the appearance of LBP may give useful recommendations and lead towards the creation of new specialized and appropriate PA programs for specific populations.

\section{REFERENCES}

Afthinos, Y., Theodorakis, N.D., \& Nassis, P. (2005). Customers' expectations of service in Greek fitness centers: Gender, age, type of sport center, and motivation differences. Managing Service Quality: An International Journal, 15(3), 245-258.

Aittomäki, A., Lahelma, E., Rahkonen, O., Leino-Arjas, P., \& Martikainen, P. (2006). The contribution of musculoskeletal disorders and physical workload to socioeconomic inequalities in health. The European Journal of Public Health, 17(2), 145-150.

Alexandris, K., Papadopoulos, P., Palialia, E., \& Vasiliadis, T. (1999). Customer satisfaction: a comparison between public and private sport and fitness clubs in Greece. European Journal for Sport Management, 6, 1-14.

Alonso-García, M., \& Sarría-Santamera, A. (2020). The economic and social burden of low back pain in Spain: a national assessment of the economic and social impact of low back pain in Spain. Spine, 45(16), E1026-E1032.

Chaory, K., Fayad, F., Rannou, F., Lefèvre-Colau, M.M., Fermanian, J., Revel, M., et al. (2004). Validation of the French version of the fear avoidance belief questionnaire. Spine, 29(8), 908-913.

Dionne, C.E., Von Korff, M., Koepsell, T.D., Deyo, R.A., Barlow, W.E., \& Checkoway, H. (2001). Formal education and back pain: a review. Journal of Epidemiology \& Community Health, 55(7), 455-468.

Đurđević, D., Mazić, S., Janković, G., \& Isaković, A. (2019). Physical activity during pregnancy and after delivery. Facta Universitatis Series Physical Education and Sport, 17(2), 277-288

Hagen, K., Zwart, J.A., Svebak, S., Bovim, G., \& Stovner, L.J. (2005). Low socioeconomic status is associated with chronic musculoskeletal complaints among 46901 adults in Norway. Scandinavian Journal of Public Health, 33(4), 268-275.

Ikeda, T., Sugiyama, K., Aida, J., Tsuboya, T., Watabiki, N., Kondo, K., et al. (2019). Socioeconomic inequalities in low back pain among older people: the JAGES cross-sectional study. International Journal for Equity in Health, 18(15), https://doi.org/10.1186/s12939-019-0918-1.

Kosmas, I., Georgiou, Y., Marmara, E., \& Fotiou, A. (2019). Evaluation of municipal fitness programs for women with low back pain. Journal of Anthropology of Sport \& Physical Education, 3(4), 33-39. 
Kosmas, I., Marmara, E., \& Stergioulas, A. (2008). Organization of traumas for women in municipal sports programs. Organization of Sport, 2, 85-90.

Lallukka, T., Mänty, M., Cooper, C., Fleischmann, M., Kouvonen, A., Walker-Bone, K.E., et al. (2018). Recurrent back pain during working life and exit from paid employment: a 28-year follow-up of the Whitehall II Study. Occupational and Environmental Medicine, 75(11), 786-791.

Leclerc, A., Gourmelen, J., Chastang, J.F., Plouvier, S., Niedhammer, I., \& Lanoë, J.L. (2009). Level of education and back pain in France: The role of demographic, lifestyle and physical work factors. International Archives of Occupational and Environmental Health, 82(5), 643-652.

Loy, B., Warner-Czyz, A.D., Tong, L., Tobey, E.A., \& Roland, P.S. (2010). The children speak an examination of the quality of life of pediatric cochlear implant users. Otolaryngology-Head and Neck Surgery, 142(2), 247-253.

Salas, E., Hulla, R., Vanzzini, N., Trowbridge, C., Brotto, M., Keller, D., et al. (2019). The relative efficacy of two exercise methods for older adults with chronic low back pain: a preliminary randomized control study. Journal of Applied Biobehavioral Research, 24(1), e12132.

Schmidt, C.O., Raspe, H., Pfingsten, M., Hasenbring, M., Basler, H.D., Eich, W., et al. (2007). Back pain in the German adult population: Prevalence, severity, and sociodemographic correlates in a multiregional survey. Spine, 32(18), 2005-2011.

Shahzad S. (2017). Social determinants of low back pain in females of reproductive age group residing in urban Lahore, Pakistan. International Archives of BioMedical and Clinical Research, 3(4).

Shiri, R., Falah-Hassani, K., Heliövaara, M., Solovieva, S., Amiri, S., Lallukka, T., et al. (2019). Risk factors for low back pain: a population-based longitudinal study. Arthritis Care \& Research, 71(2), 290-299.

Thomas, J.R., Nelson, J.K., \& Silverman, S.J. (2015). Research methods in physical activity. Human kinetics.

Vanti, C., Andreatta, S., Borghi, S., Guccione, A.A., Pillastrini, P., \& Bertozzi, L. (2019). The effectiveness of walking versus exercise on chronic low back pain and function: a systematic review and meta-analysis of randomized trials. Disability and Rehabilitation, 41(6), 622-632.

Von Korff, M., Ormel, J., Keefe, F.J., \& Dworkin, S.F. (1992). Grading the severity of chronic pain. Pain, 50(2), 133-149.

Waddell, G., Newton, M., Henderson, I., Somerville, D., \& Main, C.J. (1993). A Fear-Avoidance Beliefs Questionnaire (FABQ) and the role of fear-avoidance beliefs in chronic low back pain and disability. Pain, 52(2), 157-168.

Wami, S., Abere, G., Dessie, A., \& Getachew, D. (2019). Work-related risk factors and the prevalence of low back pain among low-wage workers: results from a cross-sectional study. BMC Public Health, 19, 1072, https://doi.org/10.1186/s12889-019-7430-9.

\section{SOCIODEMOGRAFSKI FAKTORI I BOL U DONJEM DELU LEĐA UČESNIKA ŽENSKOG POLA U OPŠTINSKIM PROGRAMIMA FIZIČKE AKTIVNOSTI}

Cilj ovog istraživanja bio je da se istraži povezanost bola u donjem delu leđa (LBP) sa faktorima nivoa obrazovanja i godina rada 131 žene, starosti $42 \pm 1.10$ godina, koje su učestvovale u fizičkim aktivnostima u okviru opštinskih programa „,Sport za sve" u Grčkoj. Da li i kako PA utiče na intenzitet boli korišćeni su upitnik o ocenjivanju težine hroničnog bola-GSCP $i$ Upitnik $u$ vezi sa izbegavanjem usled straha-FABQ. Upotrebljeni su Analiza varijanse $i$ Tuckey post-hoc kako bi se utvrdila razlika među pitanjima svakog od upitnika. Statistički značajne razlike utvrđene su u tri pitanja. Učesnice sa srednjim ili niskim nivoom obrazovanja pokazuju manje ili nikakvo poboljšanje LBP-a. Što se tiče godina rada, učesnici sa manje godina rada trpe više nivoe bola u donjem delu leđa od onih koji već rade duži vremenski period. Neophodna su buduća istraživanja odnosa određenih programa PA, sadržaja i prirode posla i pojave LBP-a.

Ključne reči: bol u donjem delu leđa, intenzitet, radno iskustvo, nivo obrazovanja 